\title{
MARKETING PERFORMANCE MEASUREMENT: MARKETING METRICS IN TURKISH FIRMS
}

\author{
Gungor Hacioglu ${ }^{1}$, Osman Gök ${ }^{2}$ \\ ${ }^{1}$ Department of Business Administration, Faculty of Economics and Administrative Sciences \\ at Biga, Canakkale Onsekiz Mart University, Biga, 17200 Canakkale, Turkey \\ ${ }^{2}$ Department of International Trade and Finance, Faculty of Economics and Administrative \\ Sciences, Yasar University, Bornova, 35500 Izmir, Turkey \\ E-mails: 1gungor.hacioglu@gmail.com (correspondingauthor); 2 osman.gok@yasar.edu.tr
}

Received 15 November 2011; accepted 08 September 2012

\begin{abstract}
This study explores which metrics are considered important in measuring marketing performance in Turkish firms. In addition, the study examines the effects of sectoral differences and market dynamism, and the relationship between the importance attached to metrics and firm performance. The data collected from a sample of 145 Turkish firms via a structured questionnaire derived from the literature reveals that the most importance is attached to consumers' attitudes metrics. Economic value added and customer lifetime value are the least important metrics in performance evaluation. No significant relationship occurs between the importance that executives attach to metrics and firm performance. Managerial implications and future research opportunities will be presented at the end. The study is, as far as is known, the first attempt at aiming to explore marketing metrics in Turkey, and one of a limited number of studies in emerging economies.
\end{abstract}

Keywords: marketing management, marketing performance, marketing metrics, marketing productivity, performance measurement, Turkey.

Reference to this paper should be made as follows: Hacioglu, G.; Gök, O. 2013. Marketing performance measurement: marketing metrics in Turkish firms, Journal of Business Economics and Management 14(Supplement 1): S413-S432.

JEL Codes: M31, L25.

\section{Introduction}

Within the last thirty years, significant changes have been observed in the management of the marketing function and in the marketing function itself (Webster 2005; Webster et al. 2005; Moorman, Rust 1999; Webster 1992). Changes in environmental factors and internal developments in organizations have resulted in questions regarding whether and how marketing departments will survive (Thomas, Gupta 2005; Piercy, Cravens 1995). The shortening of product life spans, advances in information technologies, quality improvements and the increasing expectations of customers have led marketing academics to question both the theory and the practice of marketing management (e.g. Achrol, Kotler 1999; Gök, Hacioglu 2010; Gök 2007). In this context, it has been argued that 
the marketing function has been demoted in organizational hierarchy, boards of directors have started paying less attention to marketing issues, marketing has come to be perceived as an expense instead of an investment, marketing management has been marginalized, and many strategically important elements of marketing have come to be overtaken by other departments (Nath, Mahajan 2008).

The inability of marketing managers to measure the contribution they make to overall firm performance results in marketing's loss of status within the firm (O'Sullivan, Abela 2007; Lehmann 2004; Webster et al. 2005). Brookes et al. (2004) argue that one of the five most important trends of change in marketing applications is the one towards financial measurability. The marketing function can increase its contribution to the firm by going beyond the traditional customer-product connection and placing more emphasis on financial measurability (Moorman, Rust 1999). Verhoef and Leeflang (2009), in their study using data from the Netherlands, examined the influence of the marketing department within the firm, and showed that accountability is one of the most important factors affecting the status of marketing within the firm, and that the marketing department can become more influential within the firm by becoming more measurable. This study was later repeated in seven developed economies and the same conclusions were reached (Verhoef et al. 2009).

Although assessment of marketing performance is one of the main tasks of management, very few businesses actually perform this assessment (Ambler 2000). According to a study by the Chief Marketing Officer Council, $80 \%$ of senior marketing managers report that their firms do not have a formal system for marketing performance measurement, and that they are not satisfied with their marketing programs' ability to demonstrate its contribution to business performance and value (CMO Council 2004). Thus, there is increasing pressure on the marketing function to become financially measurable (Stewart 2009; Ambler 2003; CMO Council 2004; Rust et al. 2004; Woodburn 2004; Sheth, Sisodia 2002).

If the contribution of marketing to the firm were reflected in sales and profit figures in such a way as to be clearly observed on balance sheets, things would have been easier. However, it is difficult to demonstrate the contribution of marketing to the firm because marketing tends to produce intangible assets, such as brand value, customer loyalty and the ability to understand market trends (Srinivasan, Hanssens 2009). In this context, the question of which measurement tools are the most appropriate for measuring marketing performance is being discussed both by practitioners and academics (Frösen 2008; Lenskold 2007; Patterson 2007; Ambler 2006; Grönholdt, Martensen 2006).

Some conceptual and theoretical studies have been conducted on marketing performance and its importance has been duly underlined, but there are very few studies on the metrics to be used in performance measurement.

This study will examine the importance managers attached to marketing metrics in measuring their marketing performance in Turkey, along with influences and effects. It will explore the effects of the sector within which individual firms operate and of market dynamism on the relative importance attached to different metrics. Moreover, 
the study will examine the relationship between the importance attached to metrics and firm performance. The findings of the study will be compared to the findings of studies conducted in other developed and developing countries.

In the next section, the history and the conceptual framework of the issue will be presented. Then, the methodology of the fieldwork conducted as part of the study will be explained and the findings of the fieldwork will be presented. In the last sections, the findings will be discussed and compared to the findings of previous studies, and the differences and similarities between the practices in Turkey and in other countries will be underlined.

\section{Background}

Marketing metrics are internal and external quantitative performance indicators that can either be financial or non-financial, and that are subject to monitoring by top management (Ambler 2003; Ambler et al. 2001). It is obvious that metrics facilitate the cycle of marketing analysis, planning and control, help evaluate past performance, and make it possible to compare the success of the firm within the sector to the success of competitors (Bennett 2007). Performance metrics can be classified into two: financial and non-financial. Financial metrics usually come first among the metrics used to assess marketing performance (Ambler et al. 2001; Clark 1999; Eccles 1991; Sevin 1965). Profitability, sales and cash flow have, for a long time, been among the financial metrics frequently used for the evaluation of marketing performance. Market share, considered to be an antecedent of cash flow and profitability, is another metric frequently used both by scholars and practitioners (Ambler et al. 2001).

Although conventional performance metrics are based on the system of financial accounting, interest in the use of non-financial measurement tools for the assessment of marketing success started to increase in the 1980s (Seggie et al. 2007; Meyer 2004; Yeniyurt 2003; Ambler et al. 2001; Clark 2001; Clark 1999; Davidson 1999). In the 1990s, it was observed that non-financial indicators gained increasing attention, and metrics such as customer satisfaction, channel satisfaction, customer loyalty, economic value added (EVA), brand value, customer lifetime value (CLV), customer value, relationship value and the success of new product development came to be used frequently.

Non-financial metrics, such as quality, customer satisfaction and innovation are usually better predictors of the future performance of firms and their growth potential, compared to accounting reports (Eccles 1991). These metrics, which supplement conventional sales and profitability analyses, are considered to be more informative regarding the long-term performance of firms (Clark 2001). Davidson (1999) examines the reasons for the increasing interest in non-financial measurement tools for the evaluation of organizational performance, and finds that the increasing power of buyers, replacement of the manufacturing industry by the service industry, the increase in the importance of customer-focused marketing, more dynamic distribution channels, emergence of new approaches in organizational performance measurement, and new developments in brand valuation are the primary reasons. 
As a result, both the number and diversity of measurement tools have increased (Good 1992). According to Meyer (2004), the number of metrics selected should not be too many, and three financial and three non-financial metrics would suffice. Davidson (1999) proposes four criteria to shorten the long list of metrics used in marketing performance evaluation: (1) importance to analyst, (2) practical ability to report, (3) importance to management, (4) economic importance to most companies. Similarly, Cespedes and Piercy (1996) discuss a "hierarchy of interests" that indicates what is important and what is less important for an organization, and also what defines success.

Studies on the use of marketing metrics and the importance attached to them have been conducted in various countries. Ambler et al. (2001) conducted a study on the use of and importance attached to different metrics in the UK. A similar studies were conducted in China (Ambler, Xiucun 2003), in Spain (Eusebio et al. 2006), in Finland (Frösen 2008), in Vietnam (Farley et al. 2008), in Nigeria (Nwokah 2009). Those studies examined what metrics managers use, what metrics managers report, and what metrics managers feel important. These may be different, but it is emphasized that what is being measured here is the manager's judgments on which measures are important to their marketing function.

\subsection{Hypothesis development}

\subsection{The effect of market characteristics on metric choice}

A long list of metrics for marketing performance assessment is actually available to be used by most firms. However, the relative importance of each metric varies by sector (Davidson 1999). Farley et al. (2008) found that sector characteristics have a significant effect on the metrics used. Of the 22 metrics examined, the use of 10 varied significantly by sector. The use of metrics such as new customer acquisition, profitability, increase in sales and market share varied by sectoral factors such as sector growth and number of competitors in the sector (Farley et al. 2008). Eusebio et al. (2006) examined whether firms in tourism and firms in production use different metrics for marketing efficiency measurement, and found that customer related metrics such as customer satisfaction, customer loyalty, number of new customers and number of customers lost are favored more by firms in tourism.

H1a: The importance attached to metrics differs according to the sector within which a firm operates.

Market characteristics are associated with the strategy, structure, processes, and outputs of management (Goll, Rasheed 1997). Performance in general and marketing productivity in particular, are also related to the conditions and the environment within which a firm operates. This is particularly relevant if economic turbulence in the sector is creating more uncertainty (Day 1994; Jaworski, Kohli 1993; Narver, Slater 1990). Homburg et al. (1999) argue that when market related uncertainty is high, there is more need to collect market related information, and thus the strategic contribution of marketing to the firm is higher. If environmental conditions frequently change, marketing has to predict those changes; otherwise marketing's performance may be viewed with disappointment in the firm. 
In a constantly changing environment, identifying constantly changing customer needs and reacting accordingly is very important. In such an environment, managers have to focus on activities that aim to follow both customer needs and the behaviour of competitor (Appiah-Adu, Singh 1998). Song et al. (2005) demonstrated that technological turbulence affects marketing performance. Frösen et al. (2008) found that market dynamism affects both the use of and the importance attached to different metrics.

H1b: Market dynamism is positively related to the importance attached to metrics.

\subsection{The effect of the importance attached to metrics on firm performance}

Marketing capabilities play an important role in achieving business success. Some studies examine the effects of marketing capabilities of a firm on its performance in comparison to the effects of other functional capabilities (Krasnikov, Jayachandran 2008; Acar, Zehir 2010). In their meta-analysis study, Krasnikov and Jayachandran (2008) highlighted that marketing capabilities have a larger positive effect on performance compared to $\mathrm{R} \& \mathrm{D}$ and production capabilities. In their study on technology-producing firms in Taiwan, Feng et al. (2009) achieved results similar to those of Krasnikov and Jayachandran (2008). Vorhies and Morgan (2005) argue that benchmarking is frequently used in management as a mechanism of learning, but there are few empirical studies on benchmarking marketing capabilities as a tool for acquiring sustainable competitive advantage. They identify eight different marketing capabilities, demonstrate how they have a positive effect on business performance, and conclude that these marketing capabilities can be used as benchmarking criteria. In terms of the motto, "What you do depends on what you measure", the monitoring and assessment of marketing capabilities should result in the improvement of these marketing capabilities and in higher performance.

The relationship between certain metrics and firm performance has been taken up by different researchers, and the positive effect of these metrics on firm performance has been demonstrated. Customer satisfaction (Anderson et al. 1994), new product development (Pauwels et al. 2004), and customer loyalty (Chaudhuri, Holbrook 2001) are among those metrics. In their study on the relationship between customer metrics and financial performance, Gupta and Zeithaml (2006) showed that there is a positive relationship between customer satisfaction and financial performance. According to Lamberti and Noci (2010), the relationship between marketing performance and firm performance is strengthened as the firms become more customer-oriented, and the satisfaction of customer needs becomes a priority for the firm. In their study on the effects of the importance attached to the metrics on firm performance, Llonch et al. (2002) observed a weaker relationship between the two in Spain, and a stronger one in the UK.

H2: The importance attached to metrics is positively related to firm performance.

\section{Method}

\subsection{Measures}

To identify the importance attached to metrics in measuring marketing performance, the 22 -item metrics list was used. Nineteen of these items were derived from the list developed and verified by Ambler et al. (2004). To this list, three metrics, namely Customer 
Lifetime Value (CLV), Economic Value Added (EVA), and Return on Investment (ROI), which gained importance in the literature (Seggie et al. 2007) and which were included in Frösen (2008) were added. While Ambler et al. (2004) addressed both the importance attached to metrics and the use of metrics, only the latter was examined in this study. Hence, shorter, simpler scales are needed, as otherwise the response rate among timeharassed managers in emerging markets will drop to unacceptably low levels (Burgess, Steenkamp 2006). The importance attached to these metrics was identified in light of the participants' responses to the question, "Please indicate how much importance you attach to the following metrics in evaluating the success of your firm's marketing applications" with a five-point Likert Scale.

Market dynamism was measured with the rate of change in customer preferences, competitor strategies, product characteristics and technology using a five-point Likert scale ranging from 1 = Very Slow to 5 = Very Fast (Yilmaz et al. 2005). To measure a firm's general performance, its position compared to competitors in terms of the variables of customer satisfaction, customer loyalty, sales, profitability, market share, and cost was measured using a five-point Likert Scale ranging from $1=$ Much Worse to $5=$ Much Better (Verhoef, Leeflang 2009). Although measurement of firm performance by subjective evaluations is criticized in various ways, empirical studies show that information provided by people in key positions, such as marketing managers, are compatible with the actual situation of the firm (Bennett 2007). Many studies use subjective evaluations to measure the financial and market performance of firms, and subjective measurements have been shown to be compatible with objective ones (e.g. Naman, Slevin 1993).

To identify the sector within which a firm operates, respondents were asked to select one of the "retail, consumer products, consumer services, industrial products, and industrial services" options in response to the question, "Which of the sectors below best describes the sector in which your firm operates?" In addition, respondents were asked to provide information on the number of employees in their firm and annual turnover, as indicators of size, to gather information on demographic details.

\subsection{Sample and data collection}

The target population of the study consisted of the firms included on the Istanbul Chamber of Industry's (ISO) annual list of the biggest 1000 firms in Turkey, and those included on the journal Capital's list of the biggest 500 firms in Turkey (but not on the ISO 1000 list). Publicly owned firms and firms that did not want their names disclosed were excluded, and the remaining 1111 firms made up the target population of the study. At the data collection stage, managers of marketing/sales and accounting/finance departments or members of the top management of these firms were asked to fill out the questionnaires.

An e-mail and web-based data collection method was used. E-mails were sent to a total of 2415 people from 1111 firms, which took about two weeks. To increase the response rate, a second e-mail was sent two weeks after the first e-mails. The most frequent method used to examine whether there are significant differences between responders and non-responders is to compare the responses to the first e-mails with the responses 
to the second e-mails (Armstrong, Overton 1977). An independent sample t-test was conducted to examine whether there was a significant difference between the responses to the first e-mails and responses to the second e-mails, and no significant differences were detected between the two.

Of those contacted, a total of 145 people responded, giving a response rate of $6 \%$. Studies conducted over the Internet are known to have low response rates (Bech, Kristensen 2009). Another reason for the low rate of response was probably the fact that the target population consisted of high-level managers (Baruch 1999). Seventy-two of the questionnaires were returned via e-mail and 73 over the Web. An independent sample t-test was conducted to see whether there were significant differences between data returned by two different channels; no statistically significant differences were detected.

\section{Analysis and results}

\subsection{Sample profile}

Respondents represented firms that encompassed a wide range of industries including agricultural, chemical, construction, electric equipment, electronics, food processing, iron and steel, machinery, automotive, textile, software and retail. These firms were grouped under five main sector categories, i.e. retail, consumer products, consumer services, industrial products, and industrial services. It is assumed that the categorization of firms into five general sectors would facilitate the comparison and ease the analysis of the results, relating possible differences between them. About half of the respondents $(49.6 \%)$ were from firms that produced final consumer products and services, and the

Table 1. Descriptive statistics of the respondents' firm

\begin{tabular}{lcccccccccccc}
\hline $\begin{array}{c}\text { Annual } \\
\text { turnover } \\
\text { (million TL*) }\end{array}$ & $\mathrm{f}$ & $\%$ & $\begin{array}{c}\text { Number of } \\
\text { Employees }\end{array}$ & $\mathrm{f}$ & $\%$ & Sector & $\mathrm{f}$ & $\%$ & Department & $\mathrm{f}$ & $\%$ \\
\hline $0-100$ & 54 & 37.2 & $0-250$ & 41 & 28.3 & Retail & 9 & 6.2 & Marketing & 88 & 60.7 \\
\hline $101-200$ & 21 & 14.5 & $251-500$ & 31 & 21.4 & $\begin{array}{c}\text { Consumer } \\
\text { Products }\end{array}$ & 55 & 37.9 & Finance & 15 & 10.3 \\
\hline $201-300$ & 16 & 11.0 & $500-750$ & 13 & 9.0 & $\begin{array}{c}\text { Consumer } \\
\text { Services }\end{array}$ & 8 & 5.5 & $\begin{array}{c}\text { Public } \\
\text { Relation }\end{array}$ & 14 & 9.7 \\
\hline $301-400$ & 12 & 8.3 & $751-1000$ & 17 & 11.7 & $\begin{array}{c}\text { Industrial } \\
\text { Products }\end{array}$ & 69 & 47.6 & $\begin{array}{c}\text { Top } \\
\text { Management }\end{array}$ & 28 & 19.3 \\
\hline $401-500$ & 5 & 3.4 & $1001-2000$ & 24 & 16.6 & $\begin{array}{c}\text { Industrial } \\
\text { Services }\end{array}$ & 4 & 2.8 & & & \\
\hline $501-1000$ & 16 & 11.0 & $2001-5000$ & 12 & 8.3 & & & & & & \\
\hline Over 1000 & 18 & 12.4 & Over 5000 & 4 & 2.8 & & & & & & \\
\hline Missing & 3 & 2.1 & Missing & 3 & 2.1 & & & & & & & \\
\hline
\end{tabular}

Note: $* 1$ Turkish Lira $=\$ 0.6$. 
other half were from firms that produced industrial products and services. The sample was thus balanced in terms of consumer and industrial customers. About $60 \%$ of the participants were employed in marketing and sales departments, about $10 \%$ were employed in accounting or finance departments, about $10 \%$ were employed in public relations, and about $20 \%$ were from top management. Other studies also received a large portion of their respondents from among the employees of marketing departments (e.g. Moorman, Rust 1999; Verhoef, Leeflang 2009). On the other hand, $73 \%$ of the participants were in managing roles, such as a member of the board of directors, director, coordinator, general manager, manager or vice manager.

\subsection{Data analysis}

To examine the suitability of the data for factor analysis, the Kaiser-Meyer-Olkin measure of sampling adequacy was used, which was 0.779 , indicating that the data are suitable for factor analysis. The lower limit for factor loadings, which show the correlation between individual variables and relevant factors, was set as 0.50 because factor loadings over 0.50 provide better results (Hair et al. 2006). Eigenvalue was used to determine the number of factors, and only factors with eigenvalues over 1were selected. A 22-item scale developed in previous studies was used to examine the metrics used in evaluating the performance of firms' marketing applications. Results of the exploratory factor analysis (EFA) are reported in Table 2. A grouping of items to constructs slightly different than Ambler et al. (2004) was discovered. The slight differentiation occurred in the category of intermediate measures. Some items, i.e. awareness, (perceived) differentiation, brand/product knowledge, became included in the competitive measures construct. Accordingly, constructs' names were modified. All other items were placed in the construct that was hoped for.

To examine the reliability of the scales used in the study, internal consistency coefficients were used, which varied between 0.711 and 0.869 as shown in Table 2. All scales had reliability figures over 0.70 , indicating that the scales used were reliable (Hair et al. 2006).

The four items on the market dynamism scale, as expected, were represented by a single-factor structure. To measure the general performance of firms, a 6-item scale was used. The factor analysis conducted resulted in two factors with eigenvalues over 1 (3.1 and 1.2). Items on customer satisfaction and customer loyalty and items on sales, profitability, market share and costs loaded on different factors (Table 3). As such, a distinction similar to the one in the firm performance scale used by Hooley et al. (2005) emerged. The first of these factors was named customer performance, and the other was named financial performance. Combined, the two factors represent $72.2 \%$ of the total variance. Accordingly, hypothesis was extended and two hypotheses were formulated, namely $\mathrm{H} 2 \mathrm{a}$ and $\mathrm{H} 2 \mathrm{~b}$, for the effect of the importance attached to metrics on firm.

H2a: The importance attached to metrics is positively related to customer performance.

H2b: The importance attached to metrics is positively related to financial performance. 
Table 2. Exploratory Factor Analysis (EFA) results for marketing performance metrics

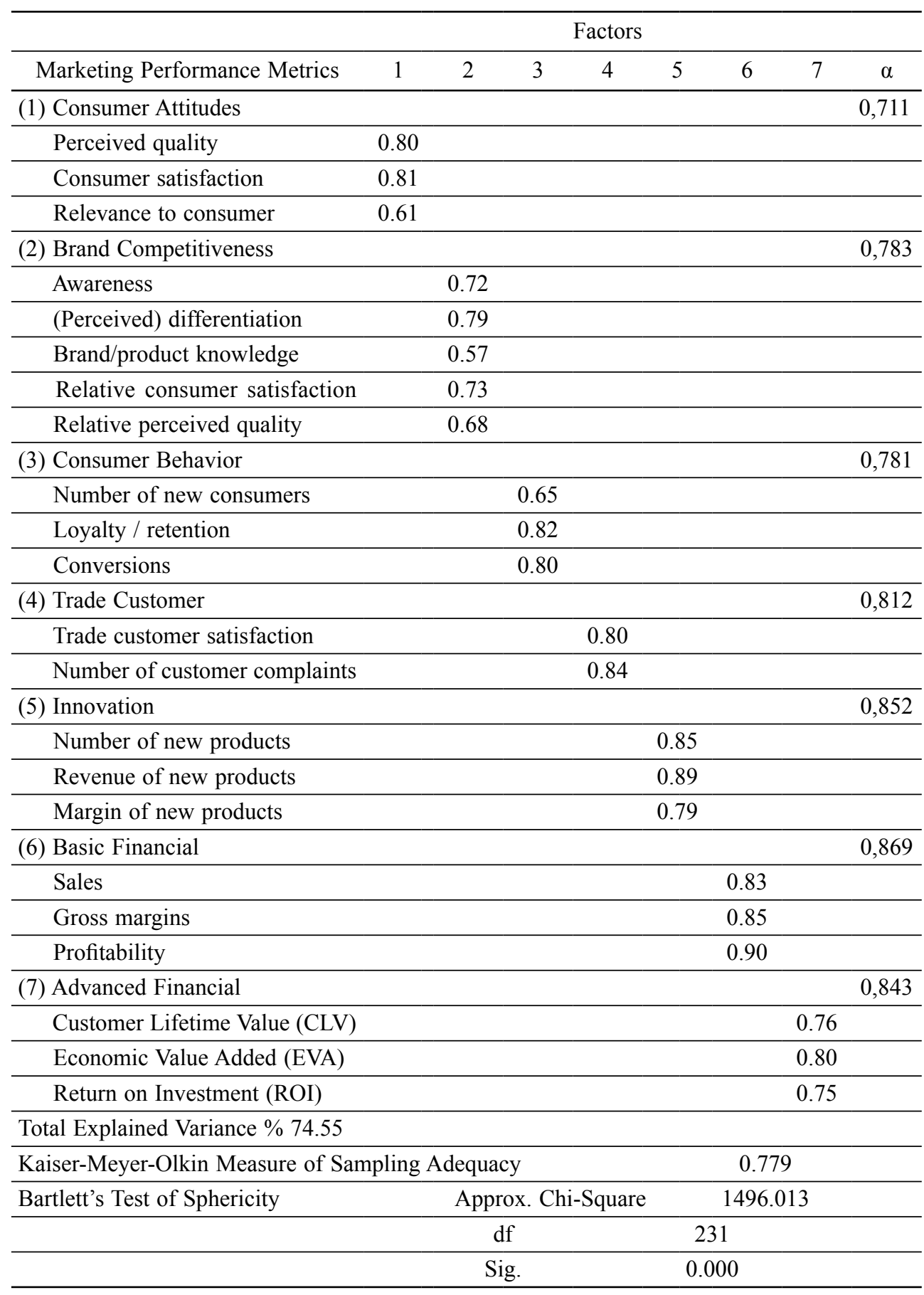

Notes: Extraction Method: Principal Component Analysis; Rotation Method: Varimax with Kaiser Normalization. 
Table 3. EFA for firm performance measures

\begin{tabular}{lccc}
\hline \multicolumn{2}{c}{ Factors } & $\alpha$ \\
\hline Performance Measures & 1 & 2 & 0,730 \\
\hline (1) Customer Performance & & & \\
\hline Customer Satisfaction & 0.875 & \\
\hline Customer Loyalty & 0.853 & & \\
\hline (2) Financial Performance & & 0.830 \\
\hline Sales & 0.855 & \\
\hline Profitability & 0.719 & \\
\hline Market Share & 0.794 & \\
\hline Cost &
\end{tabular}

Notes: Extraction Method: Principal Component Analysis; Rotation Method: Varimax with Kaiser Normalization; Rotation converged in 3 iterations.

\subsection{Hypothesis testing}

Mean values, standard deviations, and correlations are presented in Table 4. Mean values of each construct were calculated by averaging scores of items included in each construct.

Table 4. Descriptive statistics and correlation coefficients

\begin{tabular}{|c|c|c|c|c|c|c|c|c|c|c|c|c|}
\hline Variables & $\mathrm{n}$ & Mean & $\mathrm{SD}$ & 1 & 2 & 3 & 4 & 5 & 6 & 7 & 8 & 10 \\
\hline $\begin{array}{l}\text { 1. Consumer } \\
\text { Attitudes }\end{array}$ & 143 & 4.49 & 0.47 & 1 & & & & & & & & \\
\hline $\begin{array}{l}\text { 2. Brand } \\
\text { Competi- } \\
\text { tiveness }\end{array}$ & 143 & 4.16 & 0.61 & $0.437 * *$ & 1 & & & & & & & \\
\hline $\begin{array}{l}\text { 3. Consumer } \\
\text { Behavior }\end{array}$ & 143 & 3.95 & 0.74 & $0.345^{* *}$ & $0.493 * *$ & 1 & & & & & & \\
\hline $\begin{array}{l}\text { 4. Trade } \\
\text { Customer }\end{array}$ & 142 & 3.99 & 0.96 & $0.222 * *$ & $0.232 * *($ & $0.384 * *$ & 1 & & & & & \\
\hline 5. Innovation & 142 & 3.61 & 0.95 & $0.339 * *$ & $0.217 * *$ & $0.329 * *$ & $0.279 *$ & 1 & & & & \\
\hline $\begin{array}{ll}\text { 6. } & \text { Basic } \\
\text { Financial } \\
\text { Measures }\end{array}$ & 142 & 4.32 & 0.87 & 0.159 & $0.180^{*}$ & $0.313 * *$ & $0.221 *$ & $* 0.431 * *$ & 1 & & & \\
\hline $\begin{array}{l}\text { 7. Advanced } \\
\text { Financial } \\
\text { Measures }\end{array}$ & 141 & 3.45 & 1.09 & $0.396 * *$ & $0.377 * *$ & $0.479 * *$ & $0.467 *$ & $* 0.352 * *$ & $* 0.336 * *$ & 1 & & \\
\hline $\begin{array}{l}\text { 8. } \text { Market } \\
\text { Dynamism }\end{array}$ & 144 & 3.39 & 0.78 & 0.143 & 0.038 & 0.094 & 0.003 & $0.363 * *$ & * 0.136 & 0.121 & 1 & \\
\hline $\begin{array}{l}\text { 9. Customer } \\
\text { Perfor- } \\
\text { mance }\end{array}$ & 144 & 4.16 & 0.65 & $0.309 * *$ & $0.358 * *$ & 0.075 & 0.091 & 0.026 & -0.070 & 0.149 & 0.052 & 1 \\
\hline $\begin{array}{l}\text { 10. Financial } \\
\text { Perfor- } \\
\text { mance }\end{array}$ & 143 & 3.78 & 0.68 & 0.121 & 0.062 & 0.033 & 0.077 & 0.156 & 0.157 & $0.168^{*}$ & $0.197 *$ & $0.389 * * 1$ \\
\hline
\end{tabular}

Notes: * Correlations are significant at the 0.05 level; ** Correlations are significant at the 0.01 level. 


\subsubsection{Sector - the importance attached to metrics}

The relationship between the sector and the importance attached to the metric category was examined using ANOVA analysis. The analysis revealed that the effect of the sector on the importance attached to metric categories is statistically significant only in the category of trade customers. Manufacturing companies differed from firms in service industries in that they attached significantly greater importance to metrics on trade customers. Thus, hypothesis H1a was partially supported.

\subsubsection{Market dynamism - the importance attached to metrics}

The relationship between the level of dynamism in the sector and the importance attached to each of the metric categories was examined using linear regression analysis. Results of the regression analysis showed that a dynamic market structure had a statistically significant but limited effect only on the category of innovation (Table 5). The dynamic structure of the market explains only $12 \%$ of the total variance in importance attached to innovation. Market dynamism did not explain the importance attached to any of the remaining metric categories. Thus, hypothesis H1b was partially supported.

Table 5. Regression analysis results for market dynamism and metrics

\begin{tabular}{lccccc}
\hline \multicolumn{1}{c}{ Dependent Variables } & $\mathrm{S}$. Beta & $\mathrm{t}$ & $\mathrm{F}$ & Adj. $\mathrm{R}^{2}$ & $\mathrm{p}$ \\
\hline Consumer Attitudes & 0.143 & 1.720 & 2.960 & 0.014 & 0.088 \\
\hline Brand Competitiveness & 0.038 & 0.451 & 0.203 & -0.006 & 0.653 \\
\hline Consumer Behavior & 0.094 & 1.117 & 1.248 & 0.002 & 0.266 \\
\hline Trade Customer & 0.003 & 0.038 & 0.001 & -0.007 & 0.970 \\
\hline Innovation & 0.363 & 4.605 & 21.204 & 0.125 & 0.000 \\
\hline Basic Financial Measures & 0.136 & 1.628 & 2.652 & 0.012 & 0.106 \\
\hline Advanced Financial Measures & 0.121 & 1.437 & 2.064 & 0.008 & 0.153 \\
\hline
\end{tabular}

\subsubsection{The importance attached to metrics - firm performance}

Results of the multiple regression analysis indicated that a significant relationship existed between the importance attached to metrics and firms' customer performance (Table 6). Importance attached to the metrics explains $14 \%$ of the total variance in customer performance. Of the individual metric categories, only Consumer attitudes and brand competitiveness categories had significant relationships with customer performance. Thus, hypothesis H2a was supported.

To examine the relationship between the importance attached to metrics and financial performance, a multiple regression analysis was used. Results of the analysis revealed that firms' financial performance could not be explained by the importance attached to any of the metrics (Table 7). Thus, hypothesis H2b was not supported. 
Table 6. Regression analysis results for metrics and firm's customer performance

\begin{tabular}{lccc}
\hline \multicolumn{1}{c}{ Independent Variables } & $\mathrm{S}$. Beta & $\mathrm{t}$ & $\mathrm{p}$ \\
\hline Consumer Attitudes & 0.216 & 2.308 & 0.023 \\
\hline Brand Competitiveness & 0.341 & 3.548 & 0.001 \\
\hline Consumer Behavior & -0.153 & -1.545 & 0.125 \\
\hline Trade Customer & 0.034 & 0.368 & 0.714 \\
\hline Innovation & -0.040 & -0.429 & 0.669 \\
\hline Basic Financial Measures & -0.114 & $-1,287$ & 0.200 \\
\hline Advanced Financial Measures & 0.043 & 0.431 & 0.667 \\
\hline $\mathrm{F}=4.399$ Adj. $\mathrm{R}^{2}=0.147 \mathrm{p}=0.000$ & & & \\
\hline
\end{tabular}

Table 7. Regression analysis results for metrics and firm's financial performance

\begin{tabular}{lccc}
\hline \multicolumn{1}{c}{ Independent Variables } & $\mathrm{S}$. Beta & $\mathrm{t}$ & $\mathrm{p}$ \\
\hline Consumer Attitudes & 0.073 & 0.721 & 0.472 \\
\hline Brand Competitiveness & -0.006 & -0.055 & 0.957 \\
\hline Consumer Behavior & -0.124 & -1.153 & 0.251 \\
\hline Trade Customer & 0.000 & 0.001 & 0.999 \\
\hline Innovation & 0.098 & 0.979 & 0.329 \\
\hline Basic Financial Measures & 0.101 & 1.055 & 0.293 \\
\hline Advanced Financial Measures & 0.121 & 1.120 & 0.265 \\
\hline
\end{tabular}

$\mathrm{F}=1.138$ Adj. $\mathrm{R}^{2}=0.007 \mathrm{p}=0.344$

\section{Discussions and conclusions}

\subsection{The importance attached to marketing metrics - an international perspective}

Table 8 presents the findings of the study with the results of previous research. Despite the fact that the items can differ between countries, construct scores can still be compared across countries and across different studies, due to calibration of the model on a common scale (Burgess, Steenkamp 2006). Thus, it will be possible to compare the results of this study on Turkey with the results of previous studies in other countries, leading to more useful and meaningful conclusions.

Of the 22 marketing metrics, consumer satisfaction is the one seen as the most important in Turkey in evaluating marketing performance. The consumer attitude category, which included perceived quality, relevance to consumer and consumer satisfaction, was the metric category seen as the most important. It is the metric category seen as the most important in China as well, but it is seen as the least important in Nigeria. Data on customers are the most important component of the market data that firms collect, and customers are considered to be the real source of firm revenues. Many managers report 
Table 8. Inter-cultural comparison of importance score means

\begin{tabular}{lcccccc}
\hline \multicolumn{1}{c}{ Metric Categories } & Turkey & UK & Ireland & Spain & China & Nigeria \\
\hline Consumer Attitudes & 4.49 & 5.42 & 5.30 & 5.51 & 4.90 & 3.72 \\
\hline Basic Financial Measures & 4.32 & 6.51 & 6.40 & 5.15 & 4.29 & 4.35 \\
\hline Brand Competitiveness & 4.16 & 5.42 & 5.60 & 5.01 & 4.42 & 4.15 \\
\hline Trade Customer & 3.99 & 5.53 & 5.30 & 4.19 & 3.69 & 4.12 \\
\hline Consumer Behavior & 3.95 & 5.38 & 5.50 & 5.68 & 4.50 & 4.00 \\
\hline Innovation & 3.61 & 5.04 & 5.00 & 5.94 & 4.28 & 4.41 \\
\hline Advanced Financial Measures & 3.45 & - & - & - & - & - \\
\hline Mean & 4.01 & 5.58 & 5.56 & 5.19 & 4.24 & 4.21 \\
\hline
\end{tabular}

Notes: UK: Ambler et al. (2001); Ireland: O'Sullivan (2007); Spain: Llonch et al. (2002); China: Ambler and Xiucun (2006); Nigeria: Nwokah (2009). 5-point Likert scale was used in Turkey and Nigeria, 7-point Likert scale in other countries.

that they have been following non-financial metrics on customers for a long time. Nonfinancial metrics should be given a level of importance that is greater than or at least equal to the level of importance given to financial metrics in developing firm strategies and other tactical activities. So long as this does not happen, financial metrics will keep looming larger (Eccles 1991). Thus, Gupta and Zeithaml (2006) argue that managers are aware of the importance of the customers, but nevertheless continue to heavily favor financial indicators.

Financial metrics such as sales, profitability, and the ratio of gross profit to sales come second, in terms of the importance attached to metric categories. In terms of the importance attached to individual metrics, sales come second after consumer satisfaction in performance evaluation. Studies conducted in developed countries such as the UK, Finland and Ireland show that basic financial metrics constitute the metric category seen most important. The fact that financial indicators come second in Turkey after consumer satisfaction in evaluating marketing performance may indicate that firms are not really patient in reaching the financial outcomes of consumer satisfaction and cannot think long-term. Similarly, innovation comes first in Nigeria, but it is followed by financial indicators. However, it takes time to acquire financial outcomes from innovation.

The dimension of competitiveness comes third in Turkey after financial indicators. Competitiveness metrics come immediately after financial indicators in all countries except for China. Metrics on consumer behaviors, i.e. number of new consumers, loyalty/retention and conversions, come in fifth place in Turkey. We can thus argue that Turkish firms do attach a great importance to consumer attitudes, but do not care much about how these attitudes are reflected in consumer behaviors. Although metrics such as consumer satisfaction and perceived quality are stated to be very important, they do not seem to be given due priority in operational processes. Innovation is one of the least important metrics in Turkey, and one that is seen as less important in evaluating market- 
ing performance. This finding parallels the findings of studies on developed countries such as the UK, Ireland and Finland (Ambler et al. 2001; Frösen et al. 2008; O'Sullivan 2007). Verhoef and Leeflang (2009) also found that innovation is one of the marketing capabilities with the lowest scores among the capabilities of marketing departments.

\subsection{Factors affecting the importance attached to metrics}

Different market variables are thought to affect the importance attached to metrics used in evaluating marketing performance. Thus, the effects of market dynamism on the importance attached to the metrics were explored. With regards to the relationship between the sector and the metric category, it was found that only the importance attached to trade customers metrics varied significantly by sector. This finding parallels the findings of studies on other countries (Franchi 2007; Barwise, Farley 2004; Ambler, Xiucun 2003). There is no significant difference between the importance attached to trade customers metrics by firms in consumer markets and firms in industrial markets. Rather, firms in the service sector attach a smaller importance to this category. The category to which firms in consumer markets attach the greatest importance is financial indicators, whereas the category to which firms in industrial markets attach the greatest importance is consumer attitudes metrics. Because firms in industrial markets form stronger, more intensive and long-term relationships with a relatively smaller number of customers, customer attitudes in these markets are more vital. Market dynamism explains, to a limited degree, the importance attached to the innovation dimension. It was found that market dynamism is not a significant predictor of the importance attached to other metrics in the case of Turkey.

\subsection{The effect of the importance attached to metrics on firm performance}

This study also explored whether the importance attached to metrics is an indicator of the overall performance of firms. The importance attached to metrics does not have a significant effect on firms' financial performance. Only advanced financial metrics and firms' financial performance were found to be correlated. On the other hand, the importance attached to metrics did have a significant effect on customer performance. The importance attached to consumer attitudes and brand related metrics in particular, significantly increased the customer performance of firms. A study on the UK (Ambler et al. 2001) found a significant relationship between the importance attached to metrics and firm performance. However, other studies on the relationship between the importance attached to metrics and firm performance (Farley et al. 2008; O'Sullivan 2007; Ambler, Xiucun 2003) have reported very low correlation coefficients in the multiple regression analysis.

The reason there is a lack of a significant relationship between the importance attached to metrics and financial performance may be that firms attach cognitive importance to elements such as customers and competitors, but fail to reflect this recognition in their behaviors when collecting and evaluating market data, using these data as inputs in the development of firm strategies and the planning of daily activities. Moreover, it can be attributed to the relatively recent history of marketing performance measurement and assessment in Turkey. Another reason may be that firms in emerging economies like 
Turkey are more production oriented and lack sufficient market orientation. Farley et al. (2008) proposed another explanation that the effect of metrics on firm performance is complex and indirect. Micheli and Manzoni (2010) argue that the problem is not inaccuracies in the data collected, but the level at which collected data are taken into consideration. If performance indicators are taken into consideration only at the operational level, then they will never have the chance to affect firms' strategic decisions. Thus, for performance measurement to be an effective tool, performance indicators need to be associated with strategy and taken into consideration during strategic reviews.

\subsection{Managerial implications}

Selection of the appropriate metrics to be used in marketing performance evaluation should not be the only point of discussion. Measurement provides market information, but for this information to generate value, the firm needs to have a learning orientation. When departmentalism or functional orientation is high within a firm, the marketing department may be reluctant to share the market data with other departments. Marketing managers should aim to improve inter-departmental harmony so that marketing capabilities are improved and make a bigger contribution to business performance, instead of focusing narrowly on increasing their department's role within the firm.

Furthermore, Micheli and Manzoni (2010) argue that performance measurement systems cannot improve business performance in isolation from everything else, but need to be used as part of a whole in combination with rituals, award systems, and training programs. The development and spread of performance evaluation dashboards with the advances in technology enable a faster and more effective collection of market information and the sharing of this information with other departments. Managers should make sure that these performance monitoring and assessment tools are used more efficiently within the firm. Thus, it would be possible for all units to contribute to the steps needed to make use of the opportunities in the market and action against threats.

Managers should select an optimum number of metrics and assess performance in light of those selections. However, giving a definite number is not possible, despite the fact that various figures are mentioned by different authors. Clear and consistent metrics that are able to demonstrate the financial impact of marketing activities, which are futureoriented not past-oriented, that are long-term, and that enable various comparisons to be made should be selected (Ambler 2000; Seggie et al. 2007). In addition, metrics should not be considered in isolation, but relationship chains that demonstrate cause-effect relationships among them should be formed. Hence, managers would be able to have an idea of how much resource to allocate to which marketing activities.

Marketing does not aim to create value only for customers; it creates value for shareholders and investors as well. Thus, while designing performance evaluation systems and selecting marketing metrics, marketing managers need to take into consideration that investors care about the long-term value of the firm as well, instead of narrowly focusing on the short-term performance of the firm. Measurement of marketing performance is still a work in progress, and the road ahead is a difficult, complicated one that can only be walked in stages. Measurement of marketing performance should be seen as a journey experienced over time, not as a single output, method or business process (Wyner 2004). 


\subsection{Limitations and future research}

Data on firms were collected on the basis of a single person from each firm. Although this method is frequently used in studies of this type, collecting data on the basis of the views of more than one person for each firm would improve the accuracy and reliability of the data. Very few studies demonstrate the network of relations among metrics by analyzing the causal relationships between them. This study did not examine the relationships between measurement tools either. Future studies can contribute by taking up this aspect of the subject. The use of cross-sectional data makes it more difficult to demonstrate causal relationships. Long term studies would make the over-time effects of marketing performance evaluation and the metrics used in this evaluation more clear.

This study did not explore, either subjectively or objectively, "how successful" firms actually are in terms of the individual metrics of marketing performance. Future studies can explore the actual success of firms in terms of the measures and thus examine the effects of these on firms' overall performance. Although many studies have been conducted on the views and expectations of top management and other departments concerning marketing performance evaluation and which metrics to use in this evaluation, there are no comprehensive studies on the views and expectations of other stakeholders, such as shareholders and investors. Future studies could also take into consideration the views and priorities of other stakeholders regarding marketing performance evaluation.

Data collection and interpretation itself is not sufficient for metrics to be able to improve firm performance. This information needs to be shared with all departments and top management, and should influence all processes within the firm from strategy development to daily activities. In this context, learning orientation may contribute to transforming information into performance. Thus, future studies on the effects of learning orientation would make a valuable contribution to the literature on marketing metrics. In addition, the contribution of metrics to both marketing performance and overall performance of the firms would be affected by who evaluates the data and how. Thus, future studies could take up the issue of how and at what level metrics are evaluated in firms.

\section{References}

Achrol, R. S.; Kotler, P. 1999. Marketing in the network economy, Journal of Marketing 63(Special issue): 146-63. http://dx.doi.org/10.2307/1252108

Acar, A. Z.; Zehir, C. 2010. The harmonized effects of generic strategies and business capabilities on business performance, Journal of Business Economics and Management 11(4): 689-711. http://dx.doi.org/10.3846/jbem.2010.34

Ambler, T. 2000. Marketing metrics, Business Strategy Review 11(2): 59-66.

http://dx.doi.org/10.1111/1467-8616.00138

Ambler, T.; Kokkinaki, F.; Puntoni, S. 2001. Assessing marketing performance: the current state of metrics, Centre for Marketing Working Paper No. 01-903.

Ambler, T. 2003. Marketing and the bottom line - the marketing metrics to pump up cash flow. 2nd ed. London: Financial Times / Prentice Hall.

Ambler, T.; Xiucun, W. 2003. Measures of marketing success: a comparison between China and the United Kingdom, Asia Pacific Journal of Management 20(2): 267-281.

http://dx.doi.org/10.1023/A:1023896601290 
Ambler, T.; Kokkinaki, F.; Puntoni, S. 2004. Assessing marketing performance: reasons for metrics selection, Journal of Marketing Management 20(3): 475-498.

http://dx.doi.org/10.1362/026725704323080506

Ambler, T. 2006. Don't cave in to cave dwellers, Marketing Management 15(5): 25-29.

Anderson, E. W.; Fornell, C.; Lehmann, D. R. 1994. Customer satisfaction, market share, and profitability: findings from Sweden, Journal of Marketing 58(3): 53-66.

http://dx.doi.org/10.2307/1252310

Appiah-Adu, K.; Singh, S. 1998. Customer orientation and performance: a study of SMEs, Management Decision 36(6): 385-394. http://dx.doi.org/10.1108/00251749810223592

Armstrong, J. S.; Overton, T. S. 1977. Estimating nonresponse bias in mail surveys, Journal of Marketing Research 14(3): 396-402. http://dx.doi.org/10.2307/3150783

Baruch, Y. 1999. Response rate in academic studies - a comparative analysis, Human Relations, 52 (4): 421-438. http://dx.doi.org/10.1177/001872679905200401

Barwise, P.; Farley, J. 2004. Marketing metrics: status of six metrics in five countries, European Management Journal 22(3): 257-262. http://dx.doi.org/10.1016/j.emj.2004.04.012

Bech, M.; Kristensen M.B. 2009. Differential response rates in postal and Web-based surveys among older respondents, Survey Research Methods 3(1): 1-6.

Bennett, R. 2007. The use of marketing metrics by British fundraising charities: a survey of current practice, Journal of Marketing Management 23(9): 959-989.

http://dx.doi.org/10.1362/026725707X250421

Brookes, R. W.; Brodie, R. J.; Coviello, N. E.; Palmer, R. A. 2004. How managers perceive the impacts of information technologies on contemporary marketing practices, Journal of Relationship Marketing. 3(4): 7-26. http://dx.doi.org/10.1300/J366v03n04_02

Burgess, S.; Steenkamp, J. 2006. Marketing renaissance: how research in emerging markets advances marketing science and practice, International Journal of Research in Marketing 23: 337-356. http://dx.doi.org/10.1016/j.ijresmar.2006.08.001

Cespedes, F. V.; Piercy, N. F. 1996. Implementing marketing strategy, Journal of Marketing Management 12(1-3): 135-60. http://dx.doi.org/10.1080/0267257X.1996.9964405

Chaudhuri, A.; Holbrook M. B. 2001. The chain of effects from brand trust and brand affect to brand performance: the role of brand loyalty, Journal of Marketing 65(2): 81-93.

http://dx.doi.org/10.1509/jmkg.65.2.81.18255

Clark, B. 1999. Marketing performance measures: history and interrelationships, Journal of Marketing Management 15(8): 711-732. http://dx.doi.org/10.1362/026725799784772594

Clark, B. 2001. A summary of thinking on measuring the value of marketing, Journal of Targeting, Measurement and Analysis for Marketing 9(4): 357-369.

http://dx.doi.org/10.1057/palgrave.jt.5740026

CMO Council 2004. Assessing Marketing's Value \& Impact [online], [cited 4 June, 2010]. Available from Internet: www.cmocouncil.org/resources/whitepapers/mpm_white_paper.pdf

Davidson, J. 1999. Transforming the value of company reports through marketing measurement, Journal of Marketing Management 15(8): 757-777. http://dx.doi.org/10.1362/026725799784772657

Day, G. S. 1994. The capabilities of market-driven organizations, Journal of Marketing 58(3): 37-52. http://dx.doi.org/10.2307/1251915

Eccles, R. G. 1991. The performance measurement manifesto, Harvard Business Review (Jan./ Feb.): 131-37.

Eusebio, R.; Llonch, J.; Belbeze, M. P. L. 2006. Measures of marketing performance: a comparative study from Spain, International Journal of Contemporary Hospitality Management 18(2): 145-155. http://dx.doi.org/10.1108/09596110610646691 
Farley, J. U.; Hoenig, S.; Lehmann, D. R.; Nguyen, H. T. 2008. Marketing metrics use in a transition economy: the case of Vietnam, Journal of Global Marketing 21(3):179-190.

http://dx.doi.org/10.1080/08911760802151811

Feng, Y. Y.; Pan, W. H.; Huang, Y. C.; Chen, Y. K. 2009. The effects of firms reseorces and capabilities on its performance on IC design industry in Taiwan, Information Technolgy Journal 8(5): 688-697. http://dx.doi.org/10.3923/itj.2009.688.697

Franchi, F. 2007. The value of marketing metrics. Unpublished master's thesis, Cranfield University.

Frösen, J. 2008. Measuring marketing performance from a shareholder performance - the use of marketing metrics in finnish companies. Unpublished master's thesis, Helsinki School of Economics (HSE).

Frösen, J.; Jaakkola, M.; Vassinen, A.; Parvinen, P.; Aspara, J. 2008. Use and perceived importance of marketing metrics in different business settings, Australian \& New Zealand Marketing Academy Conference, December 1-3, 2008, Sydney.

Good, D. 1992. A need for the revitalization of indicants of performance in the marketing organizations, Journal of Marketing Theory and Practice 1(Fall): 31-39.

Goll, I.; Rasheed, A. 1997. Rational decision-making and firm performance: the moderating role of environment, Strategic Management Journal 18(7): 583-591.

http://dx.doi.org/10.1002/(SICI)1097-0266(199708)18:7<583::AID-SMJ907>3.0.CO;2-Z

Gök, O. 2007. Marketing and marketing managers in the new era: relational perspective, Journal of American Academy of Business, Cambridge 10(2): 218-224.

Gök, O.; Hacioglu, G. 2010. The organizational roles of marketing and marketing managers, Marketing Intelligence \& Planning 28(3): 291-309. http://dx.doi.org/10.1108/02634501011041435

Grönholdt, L.; Martensen, A. 2006. Key marketing performance measures, The Marketing Review, 6(3): 243-252. http://dx.doi.org/10.1362/146934706778605287

Gupta, S.; Zeithaml, V. 2006. Customer metrics and their impact on financial performance, Marketing Science 25(6): 718-39. http://dx.doi.org/10.1287/mksc.1060.0221

Hair, F.J.; Black, C.W.; Babin, J.B.; Anderson, E.R.; Totham, L.R. 2006. Multivariate Data Analysis. 6th ed. New Jersey: Pearson Prentice Hall.

Homburg, C.; Workman J.P. Jr.; Krohmer, H. 1999. Marketing's Influence within the Firm, Journal of Marketing, 63(2): 1-17. http://dx.doi.org/10.2307/1251942

Hooley, G.J.; Greenley, G.E.; Cadogan, J.W.; Fahy, J. 2005. The performance impact of marketing resources, Journal of Business Research 58(1): 18-27.

http://dx.doi.org/10.1016/S0148-2963(03)00109-7

Jaworski, B.J.; Kohli, A.K. 1993. Market orientation: antecedents and consequences, Journal of Marketing 57(3): 53-70. http://dx.doi.org/10.2307/1251854

Krasnikov, A.; Jayachandran, S. 2008. The relative impact of marketing, research and development, and operations capabilities on firm performance, Journal of Marketing 72(4): 1-11.

http://dx.doi.org/10.1509/jmkg.72.4.1

Lamberti, L.; Noci, G. 2010. Marketing strategy and marketing performance measurement system: Exploring the relationship, European Management Journal 28(2): 139-152.

http://dx.doi.org/10.1016/j.emj.2009.04.007

Lehmann, D. 2004. Metrics for making marketing matter, Journal of Marketing 68(4): 73-75. http://dx.doi.org/10.1509/jmkg.68.4.73.42727

Lenskold, J. 2007. Marketing ROI: playying to win, Marketing Management 11(3): 31-34.

Llonch, J.; Eusebio, R.; Ambler, T. 2002. Measures of marketing success: a comparison between Spain and the UK, European Management Journal 20(4): 414-422.

http://dx.doi.org/10.1016/S0263-2373(02)00064-6 
Meyer, M. W. 2004. Finding performance: the new discipline in management, in A. Neely (Ed.). Business Performance Measurement. Cambridge: Cambridge University Press. 51-62.

Micheli, P.; Manzoni, J. F. 2010. Strategic performance measurement: benefits, limitations and paradoxes, Long Range Planning 43(4): 465-476. http://dx.doi.org/10.1016/j.lrp.2009.12.004

Moorman, C.; Rust, R. T. 1999. The role of marketing, Journal of Marketing 63(Special Issue): 180-97. http://dx.doi.org/10.2307/1252111

Murphy, G. B.; Trailer, J. W.; Hill, R. C. 1996. Measuring performance in entrepreneurship research, Journal of Business Research 36(1): 15-23.

http://dx.doi.org/10.1016/0148-2963(95)00159-X

Naman, J.; Slevin, D. 1993. Entrepreneurship and the concept of fit: a model and empirical tests, Strategic Management Journal 14: 137-153. http://dx.doi.org/10.1002/smj.4250140205

Narver, J. C.; Slater, S. F. 1990. The effect of a market orientation on business profitability, Journal of Marketing 54(3): 20-35. http://dx.doi.org/10.2307/1251757

Nath, P.; Mahajan, V. 2008. Chief marketing officers: a study of their presence in firms' top management teams, Journal of Marketing 72(1): 65-81. http://dx.doi.org/10.1509/jmkg.72.1.65

Nwokah, N. G. 2009. Customer-focus, competitor-focus and marketing performance, Measuring Business Excellence 13(3): 20-28. http://dx.doi.org/10.1108/13683040910984293

O'Sullivan, D. 2007. The measurement of marketing performance in Irish firms, Irish Marketing Review 19(1): 19-28.

O'Sullivan, D.; Abela, A. 2007. Marketing performance measurement ability and firm performance, Journal of Marketing 71(2): 79-93. http://dx.doi.org/10.1509/jmkg.71.2.79

Patterson, L. 2007. Taking on the metrics challenge, Journal of Targeting, Measurement and Analysis for Marketing 15(4): 270-276. http://dx.doi.org/10.1057/palgrave.jt.5750055

Pauwels, K.; Silva-Risso, J.; Srinivasan, S.; Hanssens, D.M. 2004. New products, sales promotions and firm value: the case of the automobile industry, Journal of Marketing 68(3): 142-156. http://dx.doi.org/10.1509/jmkg.68.4.142.42724

Piercy, N. F.; Cravens, D. W. 1995. The network paradigm and marketing organization, European Journal of Marketing 29(3): 7-34. http://dx.doi.org/10.1108/03090569510079916

Rust, R. T.; Ambler, T.; Carpenter, G. S.; Kumar, V.; Srivastava, R. K. 2004. Measuring marketing productivity: current knowledge and future directions, Journal of Marketing 68(3): 76-89.

http://dx.doi.org/10.1509/jmkg.68.4.76.42721

Seggie, S. H.; Cavusgil, E.; Phelan, S. E. 2007. Measurement of return on marketing investment: a conceptual framework and the future of marketing metrics, Industrial Marketing Management 36(6): 834-41. http://dx.doi.org/10.1016/j.indmarman.2006.11.001

Sevin, C. H. 1965. Marketing productivity analysis. New York: McGraw-Hill. http://dx.doi.org/10.1016/S0148-2963(00)00164-8

Sheth, J.; Sisodia, R. 2002. Marketing productivity issues and analysis, Journal of Business Research, 55(5): 349- 362. http://dx.doi.org/10.1016/S0148-2963(00)00164-8

Song, M.; Droge, C.; Hanvanich, S.; Calantone, R. 2005. Marketing and technology resource complementarity: an analysis of their interaction effect in two environmental contexts, Strategic Management Journal 26(3): 259-276. http://dx.doi.org/10.1002/smj.450

Stewart, D. W. 2009. Marketing accountability: linking marketing actions to financial results, Journal of Business Research 62(6): 636-643. http://dx.doi.org/10.1016/j.jbusres.2008.02.005

Thomas, J.; Gupta, R. K. 2005. Marketing theory and practice: evolving through turbulent times, Global Business Review 6(1): 95-114. http://dx.doi.org/10.1177/097215090500600107

Verhoef, P. C.; Leeflang, P. S. H. 2009. Understanding the marketing department's influence within the firm, Journal of Marketing 73(2): 14-37. http://dx.doi.org/10.1509/jmkg.73.2.14 
Verhoef, P. C.; Leeflang, P. S. H.; Natter, M.; Baker, W.; Grinstein, A.; Gustafsson, A.; Morrison, P.; Saunders, J. 2009. A cross-national investigation into the marketing departments influence within the firm, MSI Reports No 09-004: 3-29.

Vorhies, D. W.; Morgan, N. A. 2005. Benchmarking marketing capabilities for sustainable competitive advantage, Journal of Marketing 69(1): 80-94. http://dx.doi.org/10.1509/jmkg.69.1.80.55505

Webster, F. E. Jr. 2005. A perspective on the evolution of marketing management, Journal of Public Policy \& Marketing 24(1): 121-126. http://dx.doi.org/10.1509/jppm.24.1.121.63888

Webster, F. E. Jr; Malter, A. J.; Ganesan, S. 2005. The decline and dispersion of marketing competence, MIT Sloan Management Review 46(4): 35-43.

Webster, F. E. Jr. 1992. The changing role of marketing in the corporation, Journal of Marketing 56 (3): 1-17. http://dx.doi.org/10.2307/1251983

Woodburn, D. 2004. Engaging marketing in performance measurement, Measuring Business Excellence 8(4): 63-72. http://dx.doi.org/10.1108/13683040410569424

Wyner, G. 2004. The journey to marketing effectiveness, Marketing Management 13(March/ April): 8-9.

Yeniyurt, S. 2003. A literature review and integrative performance measurement framework for multinational companies, Marketing Intelligence \& Planning 21(3): 134-142.

http://dx.doi.org/10.1108/02634500310474957

Yilmaz, C.; Alpkan, L.; Ergun, E. 2005. Cultural determinants of customer- and learning-oriented value systems and their joint effects on firm performance, Journal of Business Research 58: 1340-1352. http://dx.doi.org/10.1016/j.jbusres.2004.06.002

Gungor HACIOGLU is a research assistant at Canakkale Onsekiz Mart University, Canakkale Turkey and also is a $\mathrm{PhD}$ candidate in the same university. His research interests include marketing management, marketing performance, marketing organizations.

Osman GÖK, Dr, is associate professor for marketing at Yasar University, Izmir Turkey. He has served as Vice Dean at the Faculty of Economics and Administrative Sciences and also as the Director of Graduate School at the university. Besides, he served as assistant sales manager, product manager and marketing research specialist for companies, also as a consultant and educator to several organizations in marketing management, customer satisfaction measurement, and CRM. He has studied and written widely on managing customer relationships, industrial customer satisfaction and marketing management. 